\title{
Charles Dickens' analysis of the French Revolution in a Tale of Two Cities: A critical study
}

\author{
Dr Barnabé B. OLADJEHOU
}

\author{
FLLAC, Université d'Abomey Calavi \\ Dr Ibrahim YEKINI
}

Ecole Normale Supérieure, Université d'Abomey Calavi

\begin{abstract}
In the present article, the focus is on the way Dickens captures the extremes of idealism and terror of the revolutionary period of the late 18th century. While the horrors of the French Revolution have been eclipsed for modern readers by the world wars and genocides of the twentieth century, the terrors of the French Revolution were the horror story of Dickens's time. English society is portrayed as dangerous but not lethal. Furthermore it is determinant in the interpretation A Tale of Two Cities. Paris and London (opposite cities) Paris and London constitute the true protagonists of the novel.
\end{abstract}

Keywords: French revolution, terror, British society, Paris city, horrific history.

\section{INTRODUCTION}

Charles Dickens, one of the greatest novelists in Victorian era in England was interested in the life of children, in their upbringing, in their training, the misery and the poverty of the lower class, which provides a reaction on the scale of the French Revolution.

The novel shows that Dickens regarded the condition to be an "evil" one: "since he depicts both countries as rife with poverty, injustice and violence due to the irresponsibility of the ruling elite ${ }^{1}$ ". As the novel unfolds, however, England becomes a safe haven for those escaping the violence perpetrated by the French Revolution. In this article, the social problem in A Tale of Two cities and its effect on the popular confidence in the stability of England in the eighteen-fifties is raised. So, the focus here is on the way Dickens captures the extremes of idealism and terror of the revolutionary period of the late $18^{\text {th }}$. The injustice of equal treatment for unequal crimes reflects Dickens' everpresent concern with social justice, but it hardly compares with the unrest and injustices in France. A Tale of Two Cities is crucial for interpretation of the novel, suggesting that the opposing Cities of Paris and London constitute the true protagonists in the novel, transcending the importance of the main characters.

\section{The Symbolism of Personification in a Tale of Two Cities}

In his novels, stories, and other works, Dickens placed great importance on the names he gave his characters. Here, I am going to talk about personification who is a figure of speech in which an animal, object, or idea is given human forms or characteristics. The thematic emphasis of this chapter is on the irrevocable passage of time. Dickens describes time as a "powerful enchanter" who never undoes the work he has done. The personification of time momentarily brings the reader out of the personal details of the characters in the story and back to the distant, fable-like tone of the first chapter of the novel. However, in his death, Carton gains the ability to transcend time. He is able to look into the future and see what happens to his loved ones. Carton will achieve a resurrection of sorts through the birth of Lucie and Darnay's son and grandson. Although it will be the far-reaching future, even those alive then will refer to them in terms of the past-they pass on the story of Carton's sacrifice. In this way, Carton lives up to his nickname of memory, becoming a tangible memory. Dickens was a master of this technique and used it to help create striking descriptions or moods in his novels, mainly

${ }^{1}$ Charles Dickens, A Tale of Two Cities, New York: Bentham, 1981 PP. 13. 
in A Tale of Two Cities. Then, he uses personification in different aspects. For example, in the novel, he states:

Sadly, sadly, the sun rose; it rose upon no Sadder sight than the man of good abilities and good emotions, incapable of their directed exercise, incapable of his own help and his own happiness, sensible of the blight on him, and resigning himself to let it eat him away $^{2}$.

Here, Dickens uses personification like the concept of hunger who is described as staring down from the chimneys of the poor and rattling its dry bones. He also uses personification to enrich his description of a noble's castle:

In a quarter of an hour Monseigneur was ready, and sat down alone to his sumptuous and choice supper. His chair was opposite to the window, and he had taken his soup, and was raising his glass of Bordeaux to his lips, when he put it down." What is that? "He calmly asked, looking with attention at the horizontal lines of black and stone colour ${ }^{3}$

As we read, we notice how personification in that passage serves several purposes. It not only helps create an eerie atmosphere, it also serves to comment on the life and moral character of the noble himself. By making the castle itself to comment on the action, Dickens does not have to express directly his own feeling about the noble.

Likewise, Carl Sandburg's in his poem" Chicago" describes the city as stormy, husky, brawling / city of the big shoulders. Names, for Dickens were often a type of shorthand, a way of communicating essential about a character. For example, in Hard Times, a cruel school teacher is given the name Mr. Mc Choakum child. So he wanted to make sure his readers knew his own opinion of the school master. In Bleak House, Lady Honoria Dedlock is a beautiful, but emotionally cold, aristocrat who keeps inside her a fatal secret. In A Tale of Two Cities, Striver is an arrogant and ambitions lawyer working his way up the social ladder. Another example is Lucie Marnette, whose name comes from the Latin word for "light". Dickens refers to her as a bright and shining example to inspire the other character. Through the novel, we can look for the meanings of other symbolic names.

\section{The Physical Resemblance between Darnay and Carton in a Tale of Two CITIES}

A myth is a traditional story that is told to explain natural events, human behaviour, or mysteries of the universe. Dickens explains the cause of the French Revolution with a kind of myth, a single, general universal story that stands for all the complex social, economic, political, and moral causes of the real historical event. The first and most critical coincidence in A Tale of Two Cities is the physical resemblance between Darnay and Carton, two men who love the same woman.

Dickens uses their physical resemblance to save Charles' life. In the beginning of the book, Sydney uses his appearance to help acquit Charles on charges of treason. After the trial, it is revealed that Carton is environs of Darnay because he feels that he would have successful as Darnay if he had just a different attitude. Dickens may have used the physical resemblance to show that all Carton need was an attitude change and he could be just like Darnay, since he already looked like him. In addition, he uses coincidence for the resolution when Charles' life is saved at the end of the book when Carton and Darnay switch places and Sydney is executed. Without the coincidence of Carton and Darnay's striking resemblance, the novel wouldn't have been the same. The major coincidence and problem in the novel was the fact that the nephew of the Marquis St Evrémonde just so happened to be Charles Darnay. This becomes a problem when Charles is put up on trial for the second time and it is revealed that he is the nephew of the Marquis. As we know, Sydney comes to La Force, the prison that Darnay was in, and saves the day for Lucie and commits the ultimate sacrifice. The novel would not have had an important problem without the coincidence of Charles Darnay being the nephew of the Marquis St Evrémonde.

Finally, the deciding factor for Darnay's execution was Dr Marnette's journal that he wrote while in the Bastille. The doctor coincidentally wrote that he saw Darnay's daughter's future husband, as a boy

\footnotetext{
${ }^{2}$ Charles, Dickens. A Tale of Two Cities. New York: Bentham, 1981, P.4

${ }^{3}$ Ibid . P 6.
} 
with a member of the Evrémonde family. Later on, Marnette is thrown in prison by them. Marnette writes in his journal that he denounces the Marquis and his whole family. He never knew that his sonin-law would be the little boy in the carriage, so it is a huge coincidence. This coincidence of Marnette denouncing his own son-in-law adds a lot of suspense to the story. It has the reader on the edge of his or her seat wondering what's going to happen next.

One way to think about a coincidence is as a symbolic device. Dickens uses coincidences, even farfetched ones, to show that all elements of society are linked, even if we are aware of the links. Dickens's coincidences reinforce his belief that all members of society, rich and poor, powerful and weak, are linked together, and may have responsibilities towards each other. So Dickens may have been urging his readers to feel responsible for the destinies of all members of society.

\section{The Social Causes of The French Revolution}

Many contemporaries identify the features of the "ancient Regime" as being among the causes of the Revolution. Economic factors included hunger and malnutrition in the most destitute segments of the population, due to rising bread prices, after several years of poor grain harvests. Bad harvest rising food prices, and an inadequate transportation system that hindered the shipment centers contributed greatly to the destabilization of French society in the years leading up to the revolution.

Another cause was the state's effective bankruptcy due to the enormous cost of previous wars, particularly the financial strain caused by French participation in the American Revolutionary war. The social burdens caused by war included the huge war debt, made worse by the loss of France's colonial possessions in North America and the growing commercial dominance of Great Britain. France's inefficient and antiquated financial system was unable to manage the national debt, something which was both partially caused and exacerbated by the burden of an inadequate system of taxation. These demographics had an enormous impact both inside and outside France.

In addition, the eighteenth century saw the intrusion of capitalism into everyday life. Thanks to a large expansion of overseas trade and a longer-term development of domestic trade, the money economy experienced continued growth. Although self sufficiency or local exchange remained the preponder ant way of economic life, these incursions of capitalism began drawing everyone into some form of regional and even international exchange.

Among these broad economic and population shifts, daily life in the countryside remained much the same, particularly on small family farms. Their owners and workers were known as peasants, although they differed considerably in wealth and status. A few could claim to be "living nobly", meaning they rented their land to others to work, but many were day-laborers desperate for work in exchange for a place to stay and food to eat .In the middle were others, including independent farmers, sharecroppers, and renters. Historians have estimated that in lean years 90 percent of the peasants lived at or below the subsistence level, earning only enough to feed their families. Others inhabited the countryside, most notably small numbers of noble and non-noble owners of manors, conspicuous by their dwellings, at the least. Consequently, documents on life in the countryside at this reflect the omnipresence of poverty.

Although home to the wealthy and middling, cities tended to be even more unsavory places to live than the countryside. Exposed daily to dirty air and water, urban dwellers could expect to have a shorter life span than their country brethren. As experience, a worker could theoretically move up the social hierarchy, but in practice such ascent was extremely difficult to achieve, as the limited number of masterships in any given industry tended to be passed down within a family. Thus in some trades and in some cities journeymen complained of feeling restricted and expressed greater solidarity toward their counterparts in other trades than toward their own masters.

Bread constituted the staple of most urban diets, so sharp price increases were felt quickly and were loudly protested at grain markets or at local bakers' shops. Most people directed their anger at bread suppliers rather than political authorities, although it was often the municipal and royal authorities who tried to alleviate shortages and prevent such protests. As a result, the credibility and popularity of government officials came to be linked to the functioning of the grain and bread markets.

Moreover, early modern French society was legally stratified by birth. Its three traditional divisions were the clergy [the First Estate], the nobility [the Second Estate], and the common people [The Third Estate]. Nobles ruled over commoners, but even among commoners, specific individuals (such as 
office holders) or groups (such as a particular guild or an entire town) enjoyed privileges unavailable to outsiders. Because these privileges were passed on primarily through inheritance, they tended to constrain social mobility-although without preventing it, since they could also be bought or sold. Thus individuals and groups constantly negotiated with one another and with the crown for more and better privileges maintained a close grip on eighteenth-century imaginations, writers of the Enlightenment found them too rooted in tradition and proposed that talent supersede birth as the main determinant of social standing. Even when based on merit, they argue, social differences should not be defined by law, as they were in the old regime's orders. Traditionalists countered that a hierarchy of social orders was necessary to hold society together.

When the king called for an Estates-General in 1789, the social tensions plaguing the old regime emerged as a central issue of the Revolution. Traditionally, estates representatives had belonged to one of the three orders of society, and in principle each order had an equal voice before the king. Because nobles dominated the clergy, however, the majority of representatives actually came from the two privileged orders, even though they stood for only 5 percent of the population at most. Because each voter actually would exercise one vote in the assembly; this configuration allowed the nobility two of the three votes. The king subsequently agreed to double the size of the delegation of the Third Estate, but this move failed to appease critics of the political system. Many pamphlets appeared suggesting that representatives should vote by "head" rather than by order (meaning all representtatives should vote together as a single assembly, rather than as three separate bodies representing three separate orders).

The purpose of such pamphlets was not merely to win greater representation for the Third Estate. Their authors were making the case for a new concept of society, in which commoners, especially the educated middle classes, had the same value as the other orders. Despite the social rifts surrounding the political debate of mid-1789, most contemporaries fervently sought social unity. This suggests that social unrest may not necessarily have been the basic cause of the outbreak of the Revolution. Indeed, one wonders if the nobility's fear of losing its privileges, rather than the assertiveness of the middle classes, might have been the most important factor in the events that followed.

Far beyond the deputies' meeting hall in Versailles, another kind of social unrest was brewing in the countryside. Upon hearing about the taking of the Bastille, peasants decided they, too, could press for social change through drastic actions. In the summer of 1789 hundreds of thousands mobilized to attack lords' manors and destroy the bitter symbols of seigneurialism: Weather vanes, protective walls, and especially property deeds setting forth feudal dues that peasants were required to pay the lord. When news of this rural unrest reached the newly renamed National Assembly in Paris, its deputies, feeling pressured to stay ahead of events in the countryside, responded by announcing the "abolition of feudalism". Their decrees of 4 August represented the first step toward the destruction of the theoretical basis of old regime's system of privileges. Within the year, the assembly would do away with the whole concept of nobility, setting off a vigorous anti noble propaganda campaign in the press.

Urban workers, too, found an opportunity to express their discontent, through elections to the EstatesGeneral. Elections were held in the form of neighborhood gatherings, at which participants collectively designated a representative and compiled "cahiers de doléance" (lists of grievances) to present to the king, who would communicate them to guide the representatives. Many of these petitions expressed opposition to the privileges of nobles and officeholders. The National Assembly decrees of August 1789 against privilege-which had been the centerpiece of the French social orderwere no doubt cheered by the populace.

For all its momentousness, however, the elimination of privilege did not bring an end to the social conflicts underlying the Revolution. Instead, it marked the beginning of another system of social distinctions, set forth in a new constitution introduced by the National Assembly. The most notable of these was the distinction between "active" citizens, who were granted full rights to vote and hold office, and "passive" citizens, who were subject to the same laws but could not vote or hold office. Membership in one class or the other was determined by one's income level, gender, race, religion, and profession. With the Le Chapelier Law of 1791, the National Assembly further differentiated workers from property owners and banned worker associations as being harmful to national unity.

The National Assembly seemed unwilling to grant workers full political social participation in the new society. One reason for this reluctance was the widespread fear of further unrest. Another was the 
strong belief among spokespersons for the Enlightenment that only those with a propertied stake in society could be trusted to exercise reason, or to think for themselves. Furthermore, many reformminded revolutionaries argued that economic-based "combinations" formed by workers too closely resembled corporate guilds and would impinge on the freedom of the individual.

Whatever the assembly's motives, its actions were met with strong opposition. Workers were not untrustworthy or retrograde traditionalists, they retorted, but hardworking, uncomplicated, and honest citizens, unlike the effete and "feminized" rich. Calling themselves "sans-culottes" to indicate that they wore pants, not knee breeches (a symbol of luxury), they glorified direct action, strength, candor, and patriotism, ideals that radical journalists associated with artisanal work and found lacking in property ownership alone. The fact that such radicals as EliséeLoustallot, Jacques Roux, and JacquesRéné Hébert were educated men who did not exactly work with their hands for a living led some to question whether their discussions of sans-culottes expressed ideas held by workers themselves(Monnier; 1989). Moreover, one may wonder whether the views associated with the sansculottes extended much beyond Paris. All the same, the sans-culotte concept took on increasing political significance, because those in authority saw reflected in it the genuine working man. Thus the use of the sans-culotte in radical rhetoric led contemporaries to believe that rich and poor were in conflict throughout the revolution. How this perception influenced the course of revolutionary events may be seen in the case of Gracchus Babeuf. Before the Revolution, Babeuf had been an agent for seigneurial lords, but after 1789, he became increasingly attracted to the idea of social and political egalitarianism. By 1795, he was leading a conspiracy, although his goals and plans remained vague. Nevertheless, the political authorities worried about class war; they considered him a dangerous egalitarian evolutionary and arrested him. At his trial, Babeuf delivered an inspiring attack on privateproperty and endorsed a system of property sharing that many see as a forerunner of socialism.

In rural areas cleavages were as deeply rooted as in the cities. Peasants, in their lists of grievances of 1789 , expressed hostility to noble landlords; and, as noted earlier, this hostility intensified after Bastille Day. From July through September 1789, word of the National Assembly's decisions and of the popular revolts in Paris and other cities spread across the French countryside. It was also rumored that frightened nobles were sending groups of armed "brigands" to burn fields, steal crops, and attack villages in order to keep down the peasantry in this moment of crisis. Propelled by what became known as "the great fear," peasants in various regions of France took matters into their own hands, forming armed groups to defend their fields and their villages. The 4 August decrees, largely a response to this upheaval, initially quieted the countryside and soon cemented the peasants to the revolutionary cause.

Like the workers and small property owners in cities, peasants questioned the settlement reached by the National Assembly in 1791.In contrast to Parisian artisans, however, who began pushing for a more a-reaching revolution in 1792-94, large numbers of cultivators hankered for a return to stability in their villages. But this seemed a remote possibility as the Revolution and its wars expanded.

For the peasantry, the foremost cause of instability during the Revolution was the Civil Constitution of the Clergy of 1790.The civil constitution, like the Revolution itself, originated in the fiscal crisis that the National Assembly inherited from the crown. Needing substantial revenues, the assembly targeted church lands, which accounted for 10 percent of all landed wealth in France. The legislature divested the church of its property and in exchange took charge of its expenses and administration. The revolutionaries, imbued with the Enlightenment's criticism of the Catholic religion, suspected bishops and archbishops of resisting all change. To ensure the loyalty of parish priests, the assembly (in whose employ the priests now found themselves) added to the Civil Constitution a requirement that all clergy swear an oath of allegiance to the nation. However, almost half refused to do so. Because most "refractory priests" (those who refused the oath) lived in the countryside, the Civil Constitution-designed to promote national unity and prevent religion from becoming a source of resistance to the Revolution - instead generated considerable resentment among the peasantry. This resentment increased with the decree of 9 March 1792, authorizing the confiscation of grain to prevent "hoarding".

Thus in both towns and countryside, it seemed that the Revolution was not producing the hoped-for results. Instead of bringing unity and a quick, political resolution to the questions of 1789, as intended by its originators, The Revolution was producing further conflicts. What had happened? Had the revolutionaries expected too much? Did the fault lie with the new political elite, because they 
excluded the lower classes from the optimistic prospects for change? Or did the leaders, despite their commitment to social equality, find it impossible to avoid making private property (and the differences in wealth it necessarily generated) the cornerstone of the new society? The events of the $1790 \mathrm{~s}$ brought France no closer to determining how and whether social equality could be achieved through political measures. This very issue continues to vex modern society-long after the social stresses of 1789 have dissolved into the dustbin of history; indeed, it remains one of the most vibrant legacies of the French Revolution.

\section{Political Convulsion on the French Revolution}

A political convulsion is a fearful thing. Nobody can be assured beforehand what course it will take: we grant that too. No one ought ever to do anything which has any tendency to bring on a convulsion. But there never was an attempt made to reform any abuse in Church or State, never any denunciation uttered or mention made of any political or social evil, which had not some such tendency. Whatever excites dissatisfaction with any one of the arrangements of society, brings the danger of a forcible subversion of the entire fabric so much the nearer. Does it follow that there ought to be no censure of anything which exists? Or is this abstinence, peradventure, to be observed only when the danger is considerable? But that is whenever the evil complained of is considerable; because the greater the evil, the stronger is the desire excited to be freed from it, and because the greatest evils are always those which it is most difficult to get rid of by ordinary means. It would follow, then, that mankind are at liberty to throw off small evils, but not great ones; that the most deeply-seated and fatal diseases of the social system are those which ought to be left for ever without remedy.

Men are not to make it the sole object of their political lives to avoid a revolution, no more than of their natural lives to avoid death. They are to take reasonable care to avert both those contingencies when there is a present danger, but not to forbear the pursuit of any worthy object for fear of a mere possibility.

Unquestionably it is possible to do mischief by striving for a larger of political reform than the national mind is ripe for; and so forcing on prematurely a struggle between elements, which, by a more gradual progress, might have been brought to harmonize. And every honest and considerate person, before he engages in the career of a political reformer, will inquire whether the moral state and intellectual culture of the people are such as to render any great improvement in the management of public affairs possible. But he will inquire too, whether the people are likely ever to be made better, morally or intellectually, without a previous change in the government. If not, it may still be his duty to strive for such a change at whatever risk.

What decision a perfectly wise man, at the opening of the French Revolution, would have come to on these several points, he who knows most will be most slow to pronounce. By the Revolution, substantial good has been affected of immense value, at the cost of immediate evil of the most tremendous kind. But it is impossible, with all the light which has been, or probably ever will be, obtained on the subject, to do more than conjecture whether France could have purchased improvement cheaper; whether any course which could have averted the Revolution, would not have done so by arresting all improvement, and barbarizing down the people of France into the condition of Russian boors.

A revolution, which is so ugly a thing, certainly cannot be a very formidable thing, if all is true that Conservative writers say of it. According to them, it has always depended upon the will of some small number of persons, whether there should be a revolution or not. They invariably begin by assuming that great and decisive immediate improvements, with a certainty of subsequent and rapid progress, and the ultimate attainment of all practicable good, may be had by peaceable means at the option of the leading reformers, and that to this they voluntarily prefer civil war and massacre, for the sake of marching somewhat more directly and rapidly towards their ultimate ends. Having thus made out a revolution to be so mere a bagatelle, that, except by the extreme of knavery or folly, it may always be kept at a distance; there is little difficulty in proving all revolutionary leaders knaves or fools. But unhappily theirs is no such enviable position; a far other alternative is commonly offered to them. We will hazard the assertion, that there has scarcely ever yet happened a political convulsion, originating in the desire of reform, where the choice did not, in the full persuasion of every person concerned, lie between all and nothing; where the actors in the revolution had not thorough made up their minds, that, without a revolution, the enemies of all reform would have the entire ascendancy, and that not 
only there would be no present improvement, but the door would for the future be shut against every endeavour towards it.

Unquestionably, such was the conviction of those who took part in the French Revolution, during its earlier stages. They did not choose the way of blood and violence in preference to the way of peace and discussion. Theirs was the cause of law and order. The States General at Versailles were a body, legally assembled, legally and constitutionally sovereign of the country, and had every right which law and opinion could bestow upon them, to do all that they did. But as soon as they did anything disagreeable to the king'(s courtiers (at that time they had not even begun to make any alterations in the fundamental institutions of the country), the king and his advisers took steps for appealing to the bayonet. Then, and not till then, the adverse force of an armed people stood forth in defence of the highest constituted authority...the Legislature of their country...menaced with illegal violence. The Bastille fell; the popular party became the stronger; and success, which so often is said to be a justification, has here proved the reverse: men who would have been ranked with Hampden and Sidney if they had quietly waited to have their throats cut, passed for monsters because they had been victorious.

We have not now time nor space to discuss the quantum of the guilt which attaches, not to the authors of the Revolution, but to the various subsequent revolutionary governments, for the crimes of the Revolution. Much was done which could not have been done except by bad men. But whoever examines faithfully and diligently the records of those times... whoever can conceive the circumstances and look into the minds even of the men who planned and perpetrated those enormities, will be the more fully convinced, the more he considers the facts, that all which was done had one sole object. That object was, according to the phraseology of the time, to save the revolution; to save it, no matter by what means; to defend it against its irreconcilable enemies, within and without; to prevent the undoing of the whole work, the restoration of all that had been demolished, and the extermination of all who had been active in demolishing; to keep down the royalists, and drive back the foreign invaders; as the means to these ends, to erect all France into a camp, subject the whole French people to the obligations and the arbitrary discipline of a besieged city, and to inflict death, or suffer it, with equal readiness...death or any other evil...for the sake of succeeding in the object.

But nothing of all this is dreamed of in Mr. Alison's philosophy: he knows not enough, either of his professed subject, or of the universal subject, the nature of man, to have got even thus far, to have made this first step towards understanding what the French Revolution was .In this he is without excuse, for had he had been even moderately read in the French literature subsequent to the Revolution, he would have found this view of the details of its history familiar to every writer and reader.

\section{The Contrasts between France and England as Depicted Charles Dickens in a TAle of Two Cities}

What, then, A Tale of Two Cities signify for Dickens's readers, if the writer's fears of a massive uprising similar to the French Revolution appeared groundless? The answer may be found by a closer look at the contrasts, and not the similarities, between France and England as they are depicted in the novel. Rather than drawing readers' attention to the current problems of the country through a comparison with the condition of pre-revolutionary and revolutionary France, these contrasts serve to reaffirm the stability of England. Conrad illustrates this through the following passage:

When Lucie Marnette finds her father Dr. Marnette in Paris after his eighteen-year imprisonment in the Bastille, she tells him that they will [go to England to beat peace and at rest ${ }^{4}$.

Charles Darnay, while explaining his decision to renounce his title and privileges as a member of the aristocratic Evrémonde family, refers to England as his 'Refuge'. Jarvis Lorry complains about the difficulties of communication brought about by the Revolution between the London and Paris branches of Tellson's Bank: "At another time, our parcels would come and go, as easily as in businesslike Old England; but now, everything is stopped".

\footnotetext{
${ }^{4}$ Ibid, P 44.

${ }^{5}$ Ibid. P214.
} 
In contrast, France becomes more and more dangerous as the novel unfolds. The acts of violence committed by the revolutionary mob are among the most memorable scenes in the novel. As an example, when the Bastille is stormed, the mob kills the governor:

Remained immovable close to him when the long-gathering rain of stabs and blows fell heavy; was so close to him when he dropped dead under it, that, suddenly animated, and Madame Defarge put her foot upon his neck, and with her cruel knife long ready, hewed off his head ${ }^{6}$

It may be argued that Sydney Carton's silent prophecy about the future on his way to the guillotine compensates for the negative image of revolutionary Paris and France in the novel:

I see a beautiful city and a brilliant people rising from this abyss and in their struggles to be truly free, in their triumphs and defeats, through long years to come ${ }^{7}$

Carton prophecy seems to be inappropriate, as the novel has never given a sense that Paris is likely to become a 'beautiful' city that ennobles or is ennobled by its people:

Carton's solemn interest in the lighted windows where the people were going to rest, forgetful through a few calm hours of the horror surrounding them; in the towers of the churches, where no prayers were said, for the popular revulsion had even travelled that length of self-destruction from years of priestly impostors, plunderers, and profligates; in the distant burial-places, reserved, as they wrote upon the gates, for Eternal sleep; in the abounding goals; and in the streets along which the sixties rolled to a death which had become so common and material, that no sorrowful story of a haunting spirit ever arose among the people out at all the working of guillotine ${ }^{8}$

The novel has not shown any characters who may become the" brilliant people" of France who will make their country rise from "this abyss" in the future. Dr. Marnette comes closet; he has suffered the evils of both the ancient régime (a term referring to the rule and the way of life in France before the revolution) and revolutionary France, but his future is clearly with his daughter and son-in-law in England. None of them is likely to return after their escape, not only because it will be politically unwise, but also because a happy and safe future awaits them in England, as Carton prophecies: "I see the lives for which I lay down my life, peaceful, useful, prosperous and happy in that England which I shall see no more" .

The future awaiting the "villains of the piece", on the other hand, is death in France. In the penultimate chapter of the novel, Madame Defarge, who has been driven by a desire to see each and every descendant of the Evrémonde family executed, dies by accidentally shooting herself in a struggle with Miss Pross, Lucie's faithful maid. Although the deaths of the other "villains" are not narrated directly in the novel, Carton foresees their fate on the guillotine:

I see Barsad, and Cly, Defarge, the Vengeance, the Juryman, the Judge, long ranks of the new oppressors who have risen on the destruction of the old, perishing by this retributive instrument [the guillotine],before it shall cease out of its present use ${ }^{10}$

It is interesting to note here that Carton's list contains not only those French characters associated with the Revolution, but also two English characters, Barsad and Cly. Their careers as spies have finally brought them to Paris, where they work for the revolutionary French government. The pattern is one of poetic justice: the characters who have been depicted sympathetically will end up in England, whereas the villains, both French and English, will finally pay for their crimes on the guillotine in France.

The only character to contradict this pattern is Sydney carton, who is executed on the guillotine in Paris. However, his death is not rendered as part of the workings of poetic justice, as in the case of the villains, but rather as a divine reward. From the moment that he decides to sacrifice himself by dying

\footnotetext{
${ }^{6}$ Ibid. P245.

${ }^{7}$ Ibid. P 305.

${ }^{8}$ Ibid. P 336.

9 Ibid P.306.

${ }^{10}$ Ibid. P 310.
} 
on the guillotine instead of Darnay, he repeats the lines from the Scriptures, beginning with: "I am the Resurrection and the life ${ }^{11 "}$. This theme of resurrection reappears with Carton's prophecy where he envisions a son to be born to Lucie and Darnay, a son who will bear Carton's name. Thus he will symbolically be reborn through Lucie and Darnay's child. This vision serves another essential purpose, however. In the early parts of the novel, Lucie and Darnay have a son, who dies when yet a child. Why the vision of another child, and a son, apart from the continuation of the theme of resurrection? If the Darnay Carton family is to survive into the future, they need a son to bear their name. But much more importantly, this second son will be born free of the aristocratic stigma that has almost destroyed his father Darnay's life. In this way, the descendants of Lucie and Darnay will live as English citizens free of any association with France and its violent past. When viewed from this perspective, A Tale of Two Cities becomes a novel not about the French Revolution, but about the reaffirmation of England as a safe haven and English citizenship as something to be proud of.

\section{Conclusion}

The present article has set out to show how Charles Dickens has explored human emotions and reactions that aren't specific to any one historical event.

Throughout the novel, A Tale of Two Cities, justice was served. Their actions may have been a little severe, because of the fact that the only fair punishment at the time of the Revolution was death. The nature of Justice as exemplified in the novel shows how justice can take many forms. It can be to avenge a family member, like in the case of Madame Defarge and Gaspard, or it could be to settle the score regarding something said or done. This proves that justice has changed all the time, however, the fundamental aspects have remained the same, and the ultimate objective is to get back what you think is right and just. As Dickens wrote:

Crush humanity out of shape once more, under similar hammers, and it will twist itself into the same tortured forms. So, the same seed of rapacious license and oppression over again, and it will surely yield the same fruit according to its kind ${ }^{12}$.

In other words, human suffering isn't simply an $18^{\text {th }}$ century French problem. The novel A Tale of Two Cities, with all of the poverty and injustice it displays, is an exploration of conditions that will persist as long as violence and inequity continue to flourish.

Although A Tale of Two Cities is a major social critique, it's also an exploration of the limits of human justice. In fact, what is the theme "Justice" means exactly? Is it harming people who harm you? Or is it imprisoning people related to those people? When does Justice start becoming injustice? These are big questions. And they are still relevant today. Ask yourself if you can imagine a country in which innocent people are put in jail for political or power reasons I quote: South Africa, Nazi Germany, Libya, or about the imprisonment of Japanese Americans during the 1940s, just because they happened to look like the folks the U.S. was fighting overseas. The closer we look, the more the false imprisonment such as those relating to Dr Marnette or Charles Darnay ones becomes something that we deal with in the real life, and not just the fictional one.

\section{REFERENCES}

\section{A. Corpus}

[1] Dickens, Charles. A Tale of Two Cities. New York: Bentham, 1981

\section{B. Critics of Dickens}

[2] Altick, Richard, Victorian People and Ideas : A Companion for the Modern Reader of Victorian Literature. New York: Norton, 1973.

[3] Ascherson, Neal (Ed). The French Revolution: Extracts from the times: 1789-1794, London : Times newspapers Ltd, 1975.

[4] Blanning, T.C. The French Revolution: Aristocrats versus Bourgeois. Houndmills: Macmillan,1987.

\footnotetext{
${ }^{11}$ Ibid. P.366.

${ }^{12}$ Ibid. P. 362
} 
[5] Cowie, Leonard. The French Revolution. London : Macmillan 1992

[6] Collins, Philip, ed. Dickens : The Critical Heritage. London: Routledge, 1971.

[7] Connelly, Owen. The French Revolution and Napoleonic Era-Fort Worth: reinehart and Winston, 1991.

[8] Conway, Jack, dir. A Tale of Two Cities. MGM, 1935.

[9] Crawford, Thomas. Scott, Writers and critics. Edinburgh: Oliver and boy, 1965.

[10] Monnier, Philippe, dir. A Tale of Two Cities. Granada TV/Dune Production, 1989.

[11] Newlin, George. A Tale of TwoCities. Westport Green word, 1998.

[12] Stephen J.F. A Tale of Two Cities: Rpt in the Dickens Critics Ed. Ithaca Ford George, New York; Cornell U.P. 1966. PP 48-62.

[13] Ralph Thomas, dir. A Tale of Two Cities.London: Rank, 1958. 